Information may be had from Mr. G. E. H. Foxon, who is acting as the honorary secretary and treasurer of the Fund, at the Department of Zoology, University College, Newport Road, Cardiff, and to whom donations should be sent.

\section{Earthquakes Registered at Fiji}

THE first seismological bulletin has been received from the acting director of the Meteorological Office at Suva (Dr. W. Ralph Dyer). At this station a Milne-Shaw horizontal seismograph has been set up to register north-south movements, the co-ordinates of the station being latitude $18^{\circ} 08^{\prime} 56^{\prime \prime}$ south, longitude $178^{\circ} 27^{\prime} 26^{\prime \prime}$ east. The first earthquake to be recorded officially at this station occurred on July 31, 1943. Thirty earthquakes were registered in August, and up to September 21 twenty-two earth. quakes were registered during September. On Septem. ber 21 the seismograph was temporarily out of action owing to delays in the supply of photographic paper. The initiation of this new station is warmly welcomed. The attention of the Seismological Committee of the British Association for the Advancement of Science to this matter has been mentioned previously in the columns of NATURE, and the new station is also receiving assistance from the Dominion Observatory at Wellington, New Zealand. The Fiji Seismological Station is in an excellent position for the recording of the frequent earthquakes and tremors, a large number of which are submarine, in that Pacific region.

\section{Town and Country Planning Association}

THe Town and Country Planning Association will move to the Planning Centre, $28 \mathrm{King}$ Street, Covent Garden, London, W.C.2 on May 8. The new premises provide a room for public meetings (including the Association's fortnightly lunch-time meetings), space for exhibitions and film shows and a meeting room for the Association's members and guests. The Association's library service will be greatly extended and an information service will be made available to deal with all aspects of town and country planning. The Association has arranged an exhibition "The English Town : its Continuity and Development", which is being taken to various parts of England during the next few months, and also an exhibition and film "When We Build Again".

\section{Comet Schaumasse}

Prof. H. Shapley reports a telegram received from Strömgren and Lundmark announcing the rediscovery of this comet on March 30. The elements of its orbit and an ephemeris are"given in the "Handbook of the British Astronomical Association", 1944. Perihelion passage took place about November 27.

\section{Research into Problems of Hearing and Deafness}

BY arrangement with the Medical Research Council, an Otological Research Unit has been established at the National Hospital for Nervous Diseases, Queen Square, London, W.C.I. It is to be maintained jointly by the Councii and the Hospital, as in the case of the existing Neurological Research Unit. The director is Dr. C. S. Hallpike, a whole-time member of the Council's scientific staff and aural physician to the Hospital. The Medical Research Council, also, has appointed three new committees to advise and assist in promoting a general programme of research work into problems of deafness. They will deal with the following divisions of the subject. (a) Medical and surgical problems of the causation, prevention and treatment of deafness (chairman : Prof. H. Cohen, University of Liverpool). (b) Electro-acoustical problems relating to the design and application of instruments used in the investigation and alleviation of deafness (chairman: Dr. W. G. Radley, Post Office Research Station). (c) Problems relating to the educational treatment of deafness in children and adults (chairman : Prof. F. C. Bartlett, University of Cambridge). The membership of the committees includes nominees of Government departments and various bodies concerned with the practical questions which are involved.

\section{Birds of Ceylon}

Mr. P. Deraniragara, director of the National Museums of Ceylon, writes, pointing out that in the obituary notice of Hugh Whistler appearing in NATURE of August 21, 1943, no reference is made to his last major work, the avifaunal survey of Ceylon by the British and Colombo Museums. Whistler worked out the collections, and the results are now being printed in the Colombo Museum journal, Spolia Zeylanica; they should be published by about May.

\section{The Night Sky in May}

Futc moon occurs on May 8d. 07h. 28m. U.T., and new moon on May $22 \mathrm{~d}$. 06h. $12 \mathrm{~m}$. The following conjunctions with the moon take place: May $20 \mathrm{~d}$. 13h., Mercury $2^{\circ}$ N.; May 24d. 04h., Saturn $2^{\circ}$ N.; May 27d. 01h., Mars $1^{\circ}$ N.; May 28d. 10h., Jupiter $1^{\circ} \mathrm{S}$. There is only one occultation during May, and that is of 56 Gemi. on May 25d. 21h. $00 \cdot 1 \mathrm{~m}$. $(D)$. Mercury is in inferior conjunction on May 2 and is stationary on May 14. The planet rises about the time of sunrise in the middle of the month and forty minutes before sunrise on May 31. Venus, rising shortly before the sun throughout May, is not very well placed for observation. Mars moves from the constellation of Gemini into Cancer about the middle of May and is visible during the early part of the night. On May 1 the planet sets at 1 . and on May 31 at $23 \mathrm{~h} .48 \mathrm{~m}$. Jupiter is in the constellation of Leo and sets at $2 \mathrm{~h} .10 \mathrm{~m}$. and $0 \mathrm{~h} .19 \mathrm{~m}$. at the beginning and end of May. Saturn, in the constellation of Taurus, is drawing near the sun and sets at $23 \mathrm{~h}$. and $21 \mathrm{~h} .19 \mathrm{~m}$. at the beginning and end of the month. The $\eta$ Aquarids are active during May $1-6$ and can be seen in the early morning hours. The radiant is close to R.A. 22h. Dec. $-2^{\circ}$.

\section{Annour cements}

Sir John MarshaIL, formerly director-general of archæology in India, has been awarded the Gold Medal of the Royal Asiatic Society.

Prof. W. N. Haworth, professor of chemistry in the University of Birmingham, has been elected president of the Chemical Society.

The Committee on Nutrition Surveys, set up by the English Group of the Nutrition Society, a year ago, has drawn up a list of investigations, recent or in progress, into: (a) Consumption of Food; (b) Nutritiona] State; and (c) Effect of Supplements on Health and Efficiency. The number is unexpectedly large. A list of these investigations will be sent to anyone working on the subjects, on application to the director, Prof. J. R. Marrack, Advisory Committee on Nutrition Surveys, Bureau of Nutrition Surveys, London Hospital, E.1. 